\title{
SYMBIOTIC RELATIONSHIPS BETWEEN AGGRESSIVE Fusarium AND Alternaria FUNGI COLONIZING OAT GRAIN
}

\section{A.S. ORINA', O.P. GAVRILOVA', T.Yu. GAGKAEVA', I.G. LOSKUTOV 2 , 3}

\begin{abstract}
${ }^{1}$ All-Russian Research Institute of Plant Protection, Federal Agency of Scientific Organizations, 3, sh. Podbel'skogo, St. Petersburg, 196608 Russia, e-mail orina-alex@yandex.ru, olgavrilova1@yandex.ru, t.gagkaeva@yahoo.com (corresponding author);

${ }^{2}$ Federal Research Center the N.I. Vavilov All-Russian Institute of Plant Genetic Resources, Federal Agency of Scientific Organizations, 42-44, ul. Bol'shaya Morskaya, St. Petersburg, 190000 Russia, e-mail i.loskutov@vir.nw.ru; ${ }^{3}$ Saint-Petersburg State University, Biological Department, 7/9, Universitetskaya nab., St. Petersburg, 199034 Russia ORCID:

Orina A.S. orcid.org/0000-0002-7657-6618

Gavrilova O.P. orcid.org/0000-0002-5350-3221

Gagkaeva T.Yu. orcid.org/0000-0002-3276-561X

Loskutov I.G. orcid.org/0000-0002-9250-7225
\end{abstract}

The authors declare no conflict of interests

Acknowledgements:

Supported financially by Russian Science Foundation (project № 14-26-00067)

Received June 13, 2017

\section{Abstract}

The mycobiota of cereal grain consist of diverse fungal community among which Fusarium and Alternaria species are the most abundant. In biotic community, the competition and cooperative behavior may impact interspecies interactions. In this paper, we first report significant correlations between abundance of these fungi in oat grain. The symbiotic relationships that were found are of key importance because of mycotoxin production by Alternaria and Fusarium fungi. qPCR was used to measure Fusarium and Alternaria DNA in grain of 21 varieties and breeding lines of oats (Avena sativa and A. byzantina) from VIR World Collection (N.I. Vavilov All-Russian Institute of Plant Genetic Resources), and mycotoxin deoxynivalenol (DON) level was evaluated by ELISA test. Gere, Veler, KSI 731/01, KSI 432/08 genotypes appeared to be the most infected by both $F$. culmorum and Alternaria fungi. The highest amounts of DON (up to $1179 \mu \mathrm{g} / \mathrm{kg}$ ) occurred in the grain of the breeding line KSI 432/08, as well as in Belinda and Konkur varieties. Stipler variety was the most resistant to all studied fungi and did not accumulate DON. Oat genotypes characterized by larger grains were more susceptible to fungal infections, whereas those with high husk proportion contained more DON. A high positive correlation between the amounts of DNA of $F$. culmorum and the Fusarium species able to produce trichothecene mycotoxins (Tri-Fusarium) was shown $(r=+0.67, \mathrm{p}<0.001)$, as well as between $F$. culmorum DNA level and DON accumulation $(r=+0.57, \mathrm{p}<0.01)$. When colonizing the same substrate, aggressive Fusarium species and relatively weak Alternaria pathogens are in symbiotic relationships. In this, we found the significant positive correlations between the amounts of DNA of Alternaria fungi and $F$. culmorum $(r=+0.66, \mathrm{p}<0.01)$, and between DNA level of Alternaria and Tri-Fusarium fungi $(r=+0.86, \mathrm{p}<0.001)$. In this study, DON produced by $F$. culmorum had no allelopathic effect on Alternaria fungi. At the same time, any interspecies interactions between Alternaria fungi and $F$. poae, the most abundant species detected in oat grain, were not found. Undoubtedly, the functions of fungal complexes colonizing plants depend on the parameters of the environment and the relationships evolutionarily developed within natural communities.

Keywords: Avena L., oat, grain, fungi, Fusarium, Alternaria, DNA, qPCR, deoxynivalenol, symbiotic interactions

N.I. Vavilov wrote that the immunity of a plant to a disease must be considered as the result of the interaction of many components associated with the habitat [1]. The mutual interaction of pathogens in the mycobiota community of grain undoubtedly influences their vital activity, which ultimately affects the relations with the host plant. Therefore, selection for disease resistance can be successfully carried out only upon considering all environmental factors.

Fungi of Fusarium Link genus cause fusariosis, a harmful disease of cereals leading to a decrease in yield and deterioration of its quality. The peculiarity of this disease lies in its specific etiology, i.e. a variety of Fusarium genus species 
are involved in the infectious process. Thus, 10 to 20 species can coexist in one sample of grain with the explicit dominance of one species or group of species most adapted to the specific environmental conditions. F. culmorum (W.G. Smith) Sacc. is an aggressive pathogen of cereal crops in regions with a temperate climate, which can also infect many other plant species. The fungus is most frequently noted in Central and Northern Europe [2,3], in Russia - in the Central, Central Black Earth and North-West regions [4-6]. F. culmorum produces deoxynivalenol (DON), 3-acetate-DON and less often nivalenol [7]. These mycotoxins belong to the most widespread and studied group of trichothecene metabolites, which are a significant threat when using contaminated grains. There are models for assessing the development of fusariosis and the accumulation of mycotoxins, taking into account the influence of the variety, environment, agronomic methods, but actual fungi and mycotoxins contamination of grain does not always corresponds to the forecasted one, which in the opinion of many researchers may be due to the effect of the concomitant mycobiota [8-10]. Indeed, usually fusarium fungi are not the only ones in the grain mycobiota and coexist with its other representatives.

In nature, all fungi inevitably interact directly or indirectly - both in a contact manner in competition for the substrate and allelopathically due to the influence of secondary metabolites accumulated in the substrate as well as volatile organic compounds, the functions of which are still not sufficiently deciphered [11-13]. Fungi of the Alternaria Nees genus presented in grain alongside Fusarium fungi are isolated at a high frequency [14-16]. About 30 species of the Alternaria genus are found in grain crops, the taxonomic position of many of which remains unclear [15, 17]. Small-spore species A. alternata (Fr.) Keissl, A. tenuissima (Kunze) Wiltshire and $A$. infectoria E.G. Simmons are most often mentioned; these species have similar morphological features [17-18], which often leads to their false identification. Meanwhile, according to some data, these species differ in ability to produce secondary metabolites, for example, alternariol (AOL) [18], and, as a consequence, to affect the rest of mycobiota. It is shown that the presence of Alternaria corresponds to various contamination of grain with other fungi. Thus, it was reported that the amount of Alternaria spp. DNA in wheat correlated with the content of $F$. graminearum Schwabe DNA negatively in awns and grain [19] and A. alternata infestation reduced the accumulation of DON in grain [20]. However, other researchers, despite notable amounts of Fusarium and Alternaria DNA, did not reveal a reliable relationship between the abundance of these fungi on the grain of barley, rye and wheat [21].

Oat (Avena L.) is a hulled crop, the grain of which is largely affected by fungi of varying degrees of pathogenicity [22]; interactions between them during colonization of plant tissue have been studied insufficiently. For grain damage, there are few reports on the mutual influence of typical memers of Fusarium and Alternaria coexisting on the same substrate.

This paper is the first report on the symbiotic character of the relationship between Fusarium and Alternaria fungi living on the oat grain, which is of great practical importance, since these fungi produce mycotoxins that are dangerous to humans and animals.

Our aim was to study the interaction between typical members of the natural mycobiota of oat grain, Alternaria and Fusarium fungi, by assaying DNA of these pathogens in oat grain and mycotoxin contamination.

Techniques. The contamination of grains with Fusarium and Alternaria fungi was evaluated in breeding varieties and promising lines of Avena sativa L. (19 genotypes) and A. byzantina C. Koch (varieties Medved and CDC Dancer) of different ecogeographical origin, preserved in the VIR world collection (N.I. Vavilov All-Russian Institute of Plant Genetic Resources). The plants of each genotype 
were grown in rows of $1 \mathrm{~m}$ length in two replicates (experimental station, Pushkin, Leningrad Region, 2015). During earing, plants were inoculated with a suspension of conidia and mycelia $\left(1.3 \times 10^{7} \mathrm{CFU} / \mathrm{ml}, 50 \mathrm{ml} / \mathrm{m}^{2}\right)$ of four $F$. culmorum strains, MFG 58219, 58562, 58578, 58585 (Collection of microorganisms, Laboratory of Mycology and Pathology, All-Russian Research Institution of Plant Protection). The oats variety Borrus previously characterized as medium-resistant to grain fusariosis [23] were additionally sown as an non-inoculated control. This area was treated with sterile water.

After harvesting and threshing, 1000 grain weight at a $12 \%$ humidity was recorded and the proportion of the flower glume according to the guidelines [24]. For each genotype, 1000 grain weight was determined by weighing two 250 -grain portions per sample and doubling the obtained value. The hull content was evaluated by weighing 4 portions of grain ( 50 pieces each), two with flower glumes retained, and two with flower glumes manually removed, calculating the percentage of hull weight from the total grain weight. If the discrepancy between the two measurements did not exceed $5 \%$ of the average, this value was accepted as average weight. With greater differences, a new portion of grains was weighed and the average value between the nearest indicators was again calculated. The grain of each sample (10 g) was homogenized in sterile milling pots in a Tube Mill Control mill (IKA, Germany) at 25,000 rpm for 25 seconds. The milled meal was stored at $-20{ }^{\circ} \mathrm{C}$ until extraction of DNA and mycotoxins.

DNA was isolated from $200 \mathrm{mg}$ of grain meal by the adapted CTAB method [25]. DNA of $F$. culmorum and Alternaria alternata (Fr.) Keiss fungi strains was obtained from actively growing mycelium using a set of Genomic DNA Purification Kit reagents (Thermo Fisher Scientific, USA) in accordance with the attached protocol. The DNA concentration was evaluated in a Qubit 2.0 fluorimeter with a set of Quant-iT dsDNA HS Assay Kit reagents (Thermo Fisher Scientific, USA). Fungal DNA preparations were diluted to a concentration of $10 \mathrm{ng} / \mathrm{ml}$ and used to construct a calibration curve (10-fold serial dilutions from $10^{-1}$ to $\left.10^{-6} \mathrm{ng} / \mathrm{ml}\right)$. DNA isolated from the grain was adjusted to working concentrations of $2-50 \mathrm{ng} / \mathrm{ml}$.

The content of $F$. culmorum DNA in the meal of the grain samples was evaluated by real-time quantitative PCR (qPCR) with SYBR Green [26] stain. The reaction was performed in a volume of $20 \mu$ l containing $4 \mu \mathrm{l}$ of $5 \times$ qPCRmixHS SYBR master mix (Evrogen, Russia), $300 \mathrm{nM}$ of each primer (Evrogen, Russia) and $2 \mu \mathrm{l}$ of DNA solution. Tri-Fusarium, Alternaria and F. poae DNA concentrations were determined by the qPCR method with TaqMan fluorescent probes [27-29] in a reaction volume of $20 \mu \mathrm{l}$ containing $10 \mu \mathrm{l}$ of $2 \times$ TaqAB master mix (AlkorBio, Russia), $300 \mathrm{nM}$ of each primer, $100 \mathrm{nM}$ of fluorescent probe (Eurogen, Russia) and $2 \mu \mathrm{l}$ of DNA solution, applying the recommended protocols with the authors' modifications. Amplification was performed on a CFX96 Real-Time System thermal cycler (Bio-Rad, USA), with primary data processing using Bio-Rad CFX Manager 1.6 software. The concentration of fungal DNA was expressed as a fraction of the total DNA isolated from the oat meal (ng/ng of total DNA).

DON in the milled grain was determined by competitive enzyme immunoassay (ELISA). Mycotoxin was extracted from $1 \mathrm{~g}$ of meal by adding $5 \mathrm{ml}$ of acetonitrile:water (84:16) and allowed for 14-16 hours with continuous stirring (300 rpm) on a S-3M shaker (ELMI, Latvia). ELISA was performed using a test system with a sensitivity limit of $20 \mu \mathrm{g} / \mathrm{kg}$ (VNIIVSGE, Russia). Optical density was measured on a LEDETECT 96 (Biomed, Austria) photometer at $\lambda=492 \mathrm{~nm}$.

All laboratory tests were performed in at least two replicates. The results were processed using statistical packages of Microsoft Excel 2010 (Microsoft Cor- 
poration, USA), Statistica 10.0 (StatSoft, Inc., USA) and 4.PAST [30] software. The table shows the mean $(X)$ with a standard error $( \pm \mathrm{SE})$; the figure presents the mean $(X)$ with standard deviation $( \pm \mathrm{SD})$. The relationships between the studied indicators were evaluated by the correlation analysis using the Pearson criterion. The calculated coefficients were considered statistically significant at $\mathrm{p}<0.05$.

Results. We analyzed genotypes of oats, represented by hulled varieties and perspective lines. In these genotypes, the 1000 grain weight waried within the 29.8-46.7 g range, the proportion of flower glumes in the total biomass was 22.8$28.6 \%$ (Table 1).

1. The main parameters of oats (Avena L.) varieties and breeding lines from the VIR world collection (N.I. Vavilov All-Russian Institute of Plant Genetic Resources) used in the study (experimental station, Pushkin, Leningrad Region, 2015)

\begin{tabular}{lll|l|c}
\hline $\begin{array}{l}\text { VIR catalogue } \\
\text { No. }\end{array}$ & Variety, line & \multicolumn{1}{c}{ Origin } & $\begin{array}{l}\text { Hull content, } \% \\
(X \pm S E)\end{array}$ & $\begin{array}{l}1000 \text { grain weight, g } \\
(X \pm S E)\end{array}$ \\
\hline k-14648 & Argamak & Russia, Kirov Region & $24.5 \pm 3.2$ & $36.9 \pm 5.6$ \\
k-11840 & Borrus & Germany & $28.3 \pm 3.7$ & $34.9 \pm 5.3$ \\
k-15068 & Konkur & Russia, Ulyanovsk Region & $25.7 \pm 3.4$ & $42.5 \pm 6.9$ \\
k-10841 & Binuandorodu & Russia, Sakhalin Region & $25.6 \pm 3.4$ & $34.4 \pm 5.0$ \\
k-14329 & Kouzan Zairai & Japan & $24.5 \pm 3.2$ & $42.0 \pm 6.4$ \\
k-13911 & Kambulinskii & Russia, Leningrad Region & $25.0 \pm 3.3$ & $43.0 \pm 6.6$ \\
k-14911 & Belinda & Sweden & $25.5 \pm 3.3$ & $42.0 \pm 6.4$ \\
k-15297 & Geszty & Hungary & $22.8 \pm 2.7$ & $29.8 \pm 4.5$ \\
k-15301 & CDC Dancer & Canada & $23.7 \pm 3.1$ & $41.7 \pm 6.3$ \\
k-15506 & Fux & Germany & $24.6 \pm 3.2$ & $39.4 \pm 6.0$ \\
k-15442 & Zalp & Russia, Moscow Region & $41.5 \pm 6.3$ \\
k-15496 & Stipler & Russia, Ulyanovsk Region & $26.4 \pm 3.0$ & $44.5 \pm 6.8$ \\
k-15444 & Sapsan & Russia, Kirov Region & $24.3 \pm 3.2$ & $43.8 \pm 6.6$ \\
k-15494 & Medved & Russia, Kirov Region & $27.2 \pm 3.8$ & $46.7 \pm 7.1$ \\
k-15348 & Hurdal & Norway & $24.5 \pm 3.2$ & $42.8 \pm 6.5$ \\
k-15353 & Odal & Norway & $23.3 \pm 3.1$ & $40.4 \pm 6.1$ \\
k-15611 & Bessin & Norway & $25.3 \pm 3.3$ & $44.4 \pm 6.2$ \\
k-15612 & Veler & Norway & $24.2 \pm 3.2$ & $41.2 \pm 6.3$ \\
k-15347 & Gere & Norway & $24.0 \pm 3.1$ & $37.8 \pm 5.7$ \\
k-15326 & KSI 432/08 & Russia, Ulyanovsk Region & $28.6 \pm 3.7$ & $42.9 \pm 6.5$ \\
k-15327 & KSI 731/01 & Russia, Ulyanovsk Region & $25.0 \pm 3.3$ & $43.1 \pm 6.5$ \\
\hline
\end{tabular}

2. Primers and probes used and qPCR conditions in the study

\begin{tabular}{|c|c|c|c|}
\hline $\begin{array}{l}\text { Object } \\
\text { (reference) }\end{array}$ & Primers, probes & Nucleotide sequence $5^{\prime} \rightarrow 3^{\prime}$ & $\begin{array}{l}\text { Amplification } \\
\text { protocol }\end{array}$ \\
\hline F. culmorum & FculC561f & CACCGTCATTGGTATGTTGTCACT & $2 \mathrm{~min}$ at $50^{\circ} \mathrm{C}, 10 \mathrm{~s}$ at \\
\hline [27] & FculC614r & CGGGAGCGTCTGATAGTCG & $\begin{array}{l}95^{\circ} \mathrm{C} ; 40 \text { cycles: } 15 \mathrm{~s} \text { at } \\
95^{\circ} \mathrm{C}, 60 \mathrm{~s} \text { at } 62^{\circ} \mathrm{C}\end{array}$ \\
\hline F. poae & TMpoae,f & GCTGAGGGTAAGCCGTCCTT & $15 \mathrm{~s}$ at $95^{\circ} \mathrm{C} ; 40$ cycles: \\
\hline [28] & $\begin{array}{l}\text { TMpoae, } \mathrm{r} \\
\text { TMpoae,p }\end{array}$ & $\begin{array}{l}\text { TCTGTCCCСССТACCAAGCT } \\
\text { TET-ATTTCCCCAACTTCGACTCTCCGAGGA-BHQ1 }\end{array}$ & $\begin{array}{l}15 \mathrm{~s} \text { at } 95^{\circ} \mathrm{C}, 1 \mathrm{~min} \text { at } \\
60^{\circ} \mathrm{C}\end{array}$ \\
\hline Tri-Fusarium & TMTRI,f & CAGCAGMTRCTCAAGGTAGACCC & 3 min at $95^{\circ} \mathrm{C} ; 40$ cycles \\
\hline [29] & $\begin{array}{l}\text { TMTRI,r } \\
\text { TMTri,p }\end{array}$ & $\begin{array}{l}\text { AACTGTAYACRACCATGCCAAC } \\
\text { Cy5-AGCTTGGTGTTGGGATCTGTCCTTACCG-BHQ2 }\end{array}$ & $\begin{array}{l}15 \mathrm{~s} \text { at } 95^{\circ} \mathrm{C}, 60 \mathrm{~s} \text { at } \\
60{ }^{\circ} \mathrm{C}\end{array}$ \\
\hline Alternaria & DirITSAlt & TGTCTTTTGCGTACTTCTTGTTTCCT & 3 min at $95^{\circ} \mathrm{C} ; 40$ cycles: \\
\hline [30] & $\begin{array}{l}\text { InvITSAlt } \\
\text { AltTM }\end{array}$ & $\begin{array}{l}\text { CGACTTGTGCTGCGCTC } \\
\text { FAM-AACACCAAGCAAAGCTTGAGGGTACAAAT- } \\
\text { TAMRA }\end{array}$ & $\begin{array}{l}10 \mathrm{~s} \text { at } 95^{\circ} \mathrm{C}, 60 \mathrm{~s} \text { at } \\
60{ }^{\circ} \mathrm{C}, 3 \mathrm{~s} \text { at } 72{ }^{\circ} \mathrm{C}\end{array}$ \\
\hline
\end{tabular}

The amplification protocols are summarized in Table 2.

Along with $F$. culmorum in the grain of oats, other Fusarium fungi were identified, including those capable to synthesize mycotoxins of the trichothecene group. Therefore, we additionally estimated the DNA amount of $F$. poae which occurs in the oat grain mycobiota with a high frequency [5, 31, 32]. Also, using the group-specific primers, the amount of DNA of all Fusarium species capable of producing trichothecene mycotoxins (Tri-Fusarium), as well as DNA of Alternaria genus fungi were additionally determined.

In Borrus (non-inoculated control), fungal mass per total DNA in grain estimated by qPCR was $(1.45 \pm 0.24) \times 10^{-6} \mathrm{ng} / \mathrm{ng}$ for $F$. culmorum, $(1.73 \pm 0.02) \times 10^{-5}$ 
$\mathrm{ng} / \mathrm{ng}$ for Tri-Fusarium group, $(2.23 \pm 0.33) \times 10^{-5} \mathrm{ng} / \mathrm{ng}$ for $F$. poae, and $(6.24 \pm 0.31) \times 10^{-7} \mathrm{ng} / \mathrm{ng}$ for Alternaria. Under $F$. culmorum inoculation, the abundance of these species varied significantly. Grain level of $F$. culmorum DNA ranged from $7.39 \times 10^{-8}$ to $3.07 \times 10^{-5} \mathrm{ng} / \mathrm{ng}$ total DNA and averaged $(5.3 \pm 0.42) \times 10^{-6} \mathrm{ng} / \mathrm{ng}$ (Fig.). The total Tri-Fusarium DNA ranged from $1.5 \times 10^{-5}$ to $9.1 \times 10^{-5}$ and averaged $(5.3 \pm 0.28) \times 10^{-5} \mathrm{ng} / \mathrm{ng}, F$. poae DNA rang was $1.05 \times 10^{-5}-3.06 \times 10^{-4}$ with average value of $(7.45 \pm 0.83) \times 10^{-5} \mathrm{ng} / \mathrm{ng}$ total DNA. For Alternaria DNA, these indicators were $3.9 \times 10^{-7}$ to $5.4 \times 10^{-5}$ and $(1.07 \pm 0.6) \times 10^{-5} \mathrm{ng} / \mathrm{ng}$. Apparently, the Alternaria species are well adapted and occupies its niche among mycobiota, regardless of the influence of environmental conditions and the genotype of the host plant. The samples Gere, Veler, KSI 731/01, KSI 432/08 were the most infected by $F$. culmorum and Alternaria fungi.

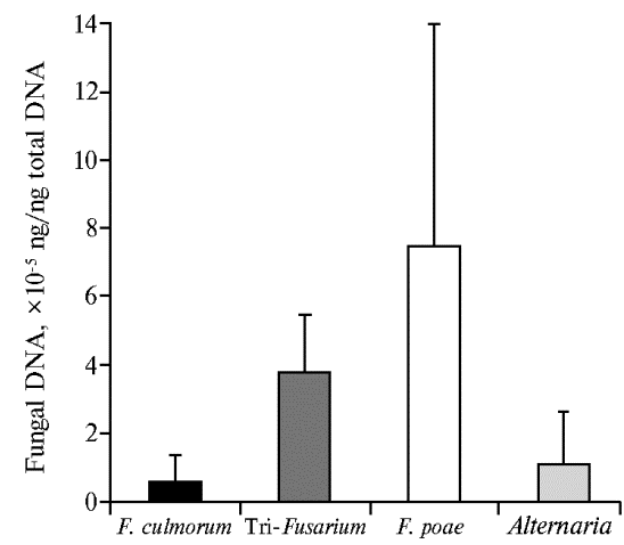

Fungal DNA in grain under oat (Avena L.) plant inoculation with a suspension of MFG 58219, 58562, 58578, 58585 Fusarium culmorum

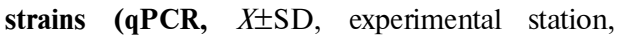
Pushkin, Leningrad Region, 2015).

The qPCR method makes it possible to evaluate the DNA content of the target in grain, but has its own limitations. Thus, the primers for quantification of Tri-Fusarium and F. culmorum species are designed based on the nucleotide sequence of genes that are present in the genome in single copies, Tri5 and $E F 1$, respectively [26, 27]. In contrast, primers for the quantitative detection of $F$. poae fungus and Alternaria species are developed based on multicopy sequences of IGS and ITS regions of ribosomal DNA [28, 33]. The primary differences between the initial quantities of the amplified fragments allow comparing infection by one or another target pathogen among the genotypes themselves, but do not allow comparing the DNA level for different objects with each other in the same sample.

ELISA showed that $100 \%$ of the analyzed oat genotypes after artificial inoculation with F. culmorum contained DON (from 25 to $1179 \mu \mathrm{g} / \mathrm{kg}, 198 \pm 57 \mu \mathrm{g} / \mathrm{kg}$ on average). The greatest quantities of mycotoxin were noted in the grain of the KSI 432/08 breeding line, as well as in the Belinda and Konkur varieties. The Stipler variety, most resistant to infection of all fungi, had $33 \mu \mathrm{g} / \mathrm{kg}$ DON. DON was not found in the grain of non-inoculated control (Borrus variety).

3. Interrelation of indicators $(r)$ in oat (Avena L.) genotypes under inoculation with Fusarium culmorum (experimental station, Pushkin, Leningrad Region, 2015)

\begin{tabular}{|c|c|c|c|c|c|}
\hline \multirow{2}{*}{$\begin{array}{ll}\text { Indicator } & \text { Indicator } \\
\end{array}$} & \multicolumn{4}{|c|}{ DNA content in grain } & \multirow{2}{*}{$\begin{array}{l}\text { DON ac- } \\
\text { cumulation }\end{array}$} \\
\hline & F. culmorum & F. poae & Tri-Fusarium & Alternaria & \\
\hline \multicolumn{6}{|l|}{ DNA content in grain: } \\
\hline F. poae & -0.34 & & & & \\
\hline Tri-Fusarium & $0.67^{* *}$ & -0.25 & & & \\
\hline Alternaria & $0.66^{* *}$ & -0.27 & $0.86^{* *}$ & & \\
\hline DON accumulation & $0.57^{*}$ & 0.19 & 0.21 & 0.18 & \\
\hline Hull fraction & 0.37 & 0.08 & -0.06 & 0.01 & $0.49 *$ \\
\hline 1000 grain weight & 0.34 & -0.25 & $0.45^{*}$ & 0.39 & 0.16 \\
\hline
\end{tabular}

Correlation analysis revealed a high reliable relationship between DNA levels of $F$. culmorum and Tri-Fusarium group $(r=+0.67, \mathrm{p}<0.001)$, which demonstrates the success of the performed inoculation (Table 3). For F. cul- 
morum, the DON producer, there was also a strong relationship between the DNA amount and DON accumulation $(r=+0.57, \mathrm{p}<0.01)$.

The 1000 grain weight value significantly correlated with the anount of Tri-Fusarium DNA $(r=+0.45, \mathrm{p}<0.05)$. Genotypes with larger grain were relatively more strongly infected with fungi, which may be due to a greater content of nutrients allowing the fungus to gain biomass. At the same time, an increase in hull fraction led to a grain significant contamination with mycotoxin DON. The flower glume prevents penetration fungi into grain rich in nutrient substrates, and contributes (probably due to structure and chemical composition) to the intensive production of secondary metabolites by Fusarium fungi.

A reliable positive relationship was between the DNA content of the Alternaria and $F$. culmorum fungi $(r=+0.66, \mathrm{p}<0.01)$ and between the Alternaria DNA level and the entire diversity of Fusarium species forming trichothecene mycotoxins $(r=+0.86, \mathrm{p}<0.001)$. Apparently, during the colonization of the common substrate by aggressive species of Fusarium and relatively weak Alternaria pathogens, mutually beneficial conditions for the development of both arise, so that their relationships can be characterized as symbiotic. Even a significant DON level in grain did not adversely affect growth of Alternaria fungi. At the same time, we did not observe any relationship between Alternaria fungi and $F$. poae pathogen, a relatively weak and the most abundant member of Fusarium genus on the grain. Consequently, no competition arises between these fungi for the nutrient substrate during oat grain colonization and their relationship can be characterized as commensalism.

It is known that some mycotoxins produced by fungi can play an important role in the relationship between fungi and host plants [2, 10, 14]. In our study, we did not find the allelopathic effect of $F$. culmorum mycotoxins on Alternaria fungi, although some researchers noted various types of interaction between representatives of these genus. In particular, the slowing of $A$. alternata growth under the influence of $F$. graminearum has been described in laboratory experiments with co-cultivation [34]. In such a mixed culture, DON production by $F$. graminearum was lower, and the production of zearalenone (ZEN) was higher than in the pure culture of this pathogen. Another group of researchers reports that the rate of colonization of wheat grains by $A$. tenuissima fungus and the amount of secondary metabolites generated, for example AOL, increased significantly if the grain was pre-treated with DON or XEN mycotoxins [35]. Grain treatment with AOL had a negligible effect on $F$. culmorum, but led to an increase in $F$. graminearum growth. At the same time, the presence of Fusarium fungi on ears did not affect the amount of AOL.

Thus, we have identified a symbiotic relationship between Alternaria and Fusarium fungi, colonizing oat grain. Statistical analysis confirmed that there is a significant positive relationship between the abundance of these fungi in grain, which is especially important when combining Alternaria fungi and the highly aggressive $F$. culmorum species. During oat grain colonization, there is no competition for the nutrient substrate between $F$. poae, which is considered a relatively weak pathogen, and Alternaria fungi, hence their relationship can be characterized as commensalism. The interaction of fungi and plants is evolutionary conditioned, and the knowledge of its mechanisms in complex ecosystems is necessary for their control.

\section{R E F E R E N C E S}

1. V a vilov N.I. Izbrannye proizvedeniya $v$ dvukh tomakh. Tom 2. Uchenie o immunitete rastenii $k$ infektsionnym zabolevaniem /Pod redaktsiei F.KH. Bakhteeva. Leningrad, 1967 (in Russ.).

2. $\mathrm{Xu} \mathrm{X}$., Nichols on P. Community ecology of fungal pathogens causing wheat head blight. 
Ann. Rev. Phytopathol., 2009, 47: 83-103 (doi: 10.1146/annurev-phyto-080508-081737).

3. Scherm B., Balmas V., S panu F., Pani G., Delogu G., Pasquali M., M igh e li Q. Fusarium culmorum: causal agent of foot and root rot and head blight on wheat. Mol. Plant Pathol., 2013, 14(4): 323-341 (doi: 10.1111/mpp.12011).

4. Levitin M.M., Ivashchenko V.G., Shipilova N.P., Nesterov A.N., Gagka eva T.Yu., P ot o r o china I.G., Af a n a s' e va O.B. Mikologiya i fitopatologiya, 1994, 28(3): 58-64 (in Russ.).

5. Gavrilova O.P., Gagka eva T.Yu., Burkin A.A., Kononenko G.P. Mycological infection by Fusarium strains and mycotoxins contamination of oats and barley grain in the north of Nonchernozem'e. Sel'skokhozyaistvennaya biologiya [Agricultural Biology], 2009, 6: 8993 (in Russ.).

6. Gagka eva T.Yu., Gavrilova O.P., Levit in M.M. Bioraznoobrazie i arealy osnovnykh toksinprodutsiruyushchikh gribov roda Fusarium. Biosfera, 2014, 6(1): 36-45.

7. Pasquali M., Beyer M., Logrieco A., Audenaert K., Balmas V., Basler R., Boutigny A.L., Chrpová J., Czembor E., Gagkaeva T., González-Jaén M.T., Hofgaard I.S., Köycü N.D., Hoffmann L., Lević J., Marin P., Miedaner T., Migheli Q., Moretti A., Müller M.E., Munaut F., Parikka P., PallezBarthel M., Piec J., Scauflaire J., Scherm B., Stanković S., Thrane U., Uhlig S., Vanheule A., Yli-Mattila T., Vogelgsang S. A European database of Fusarium graminearum and F. culmorum trichothecene genotypes. Front. Microbiol., 2016, 7: 406 (doi: 10.3389/fmicb.2016.00406).

8. $\mathrm{S} \mathrm{ch}$ a a f s m a A.W., H o o k e r D.C. Climatic models to predict occurrence of Fusarium toxins in wheat and maize. Int. J. Food Microbiol., 2007, 119: 116-125 (doi: 10.1016/j.ijfoodmicro.2007.08.006).

9. Lindblad M., Börjesson T., Hi et aniemi V., Elen O. Statistical analysis of agronomical factors and weather conditions influencing deoxynivalenol levels in oats in Scandinavia. Food Addit. Contam., 2011, 29(10): 1566-1571 (doi: 10.1080/19440049.2011.647335).

10. Mülle r M.E.H., S te i e r I., Köppen R., S i e ge l D., Proske M., Korn U., $\mathrm{Koch}$ M. Cocultivation of phytopathogenic Fusarium and Alternaria strains affects fungal growth and mycotoxin production. J. Appl. Microbiol., 2012, 113: 874-887 (doi: 10.1111/j.13652672.2012.05388.x).

11. Solom o n P.S. Assessing the mycotoxigenic threat of necrotrophic pathogens of wheat. $M y$ cotoxin Res., 2011, 27: 231-237 (doi: 10.1007/s12550-011-0108-5).

12. Savelieva E., Gustyleva L., Kessenikh E., Khlebnikova N., Leffingwe 11 J., Gavrilova O., Gagka eva T. Study of the vapor phase over Fusarium fungi cultured on various substrates. Chemistry and Biodiversity, 2016, 13(7): 891-903 (doi: 10.1002/cbdv.201500284).

13. Weikl F., Ghirardo A., Schnitzler J.-P., Pritsch K. Sesquiterpene emissions from Alternaria alternata and Fusarium oxysporum: effects of age, nutrient availability, and cocultivation. Scientific Reports, 2016, 6: 22152 (doi: 10.1038/srep22152).

14. Kosiak B., Torp M., S kje rve E., A ndersen B. Alternaria and Fusarium in Norwegian grains of reduced quality - a matched pair sample study. Int. J. Food Microbiol., 2004, 93(1): 51-62 (doi: 10.1016/j.ijfoodmicro.2003.10.006).

15. G a n nibal F.B. Mikologiya i fitopatologiya, 2008, 42(4): 359-368 (in Russ.).

16. Gavrilova O.P., Gannibal F.B., Gagkaeva T.Yu. Fusarium and Alternaria fungi in grain of oats grown in the north-western Russia regarding cultivar specificity. Sel'skokhozyaistvennaya biologiya [Agricultural Biology], 2016, 51(1): 111-118 (doi: 10.15389/agrobiology.2016.1.111eng).

17. S i m m on s E.G. Alternaria. An Identification Manual. Utrecht, CBS, 2007.

18. Andersen B., Krøger E., Roberts R.G. Chemical and morphological segregation of Alternaria arborescens, A. infectoria and A. tenuissima species-group. Mycol. Res., 2002, 106(2): 170-182 (doi: 10.1017/S0953756201005263).

19. Lević J., Stanković S., Krnjaja V., Tančić S., Ivanović D., Bočarov-Stančić A. Relationships of mycobiota on rachides and kernels of wheat. Eur. J. Plant Pathol., 2012, 134(2): 249-256 (doi: 10.1007/s10658-012-9982-8).

20. González H.H.L., Martínez E.J., Pacin A., Resnik S.L. Relationship between Fusarium graminearum and Alternaria alternata contamination and deoxynivalenol occurrence on Argentinian durum wheat. Mycopathologia, 1999, 144: 97-102.

21. Kulik T., Treder K., Załuski D. Quantification of Alternaria, Cladosporium, Fusarium and Penicillium verrucosum in conventional and organic grains by qPCR. J. Phytopathol., 2015, 163: 522-528 (doi: 10.1111/jph.12348).

22. Gavrilova O.P., Gribchenko E.S., Loskutov I.G., Gagkaeva T.Yu. Sovremennaya mikologiya $v$ Rossii, 2015, 5: 44-46 (in Russ.).

23. G a g k a e va T.Y., G a vrilova O.P., Yli- Mattila T., Loskutov I.G. The sources of resistance to Fusarium head blight in VIR oat collection. Euphytica, 2013, 191(3): 355-364 (doi: 10.1007/s10681-013-0865-7). 
24. Loskutov I.G., Kovaleva O.N., Blinova E.V. Metodicheskie ukazaniya po izucheniyu $i$ sokhraneniyu mirovoi kollektsii yachmenya $i$ ovsa [Study and preservation of world barley and oat collection - recimmendaions]. St. Petersburg, 2012 (in Russ.).

25. European commission. Community reference laboratory for GM food and feed. Event-specific for the quantitation of maize line NK603 using real-time PCR. 2005. Available http://gmocrl.jrc.ec.europa.eu/summaries/NK603report_mm.pdf. No date.

26. Nicolaisen M., Suproniene S., Nielsen L.K., Lazzaro I., Spliid N.H., J uste s e n A.F. Real-time PCR for quantification of eleven individual Fusarium species in cereals. J. Microbiol. Meth., 2009, 76: 234-240 (doi: 10.1016/j.mimet.2008.10.016).

27. H a lste nse n A.S., N o rdby K.C., Eduard W., K le m sd a 1 S.S. Real-time PCR detection of toxigenic Fusarium in airborne and settled grain dust and associations with trichothecene mycotoxins. J. Environ. Monitor., 2006, 8: 1235-1241 (doi: 10.1039/b609840a).

28. P a vón M.Á., Lu n a A., d e 1 a C ruz S., G o n zá 1 e z I., M a r tín R., G a r c í a T. PCR based assay for the detection of Alternaria species and correlation with HPLC determination of altenuene, alternariol and alternariol monomethyl ether production in tomato products. Food Control, 2012, 25(1): 45-52 (doi: 10.1016/j.foodcont.2011.10.009).

29. Yli-Mattila T., Paavanen-Huhtala S., Parikka P., Hietaniemi V., Jestoi M., Gagkaeva T., Sarli n T., Haikara A., La a k sone n S., Rizzo A. Real-time PCR detection and quantification of Fusarium poae, F. graminearum, F. sporotrichioides and $F$. langsethiae as compared to mycotoxin production in grains in Finland and Russia. Arch. Phytopathol. Pfl., 2008, 41: 243-260 (doi: 10.1080/03235400600680659).

30. H a m m e $\mathrm{r} \varnothing$., $\mathrm{H}$ a r p e r D.A.T., R y a $\mathrm{n}$ P.D. PAST: Paleontological statistics software package for education and data analysis. Palaeontologia Electronica, 2001, 4(1): 9.

31. Tekauz A., McCallum B., Ames N., Fetch J.M. Fusarium head blight of oat - current status in western Canada. Can. J. Plant Pathol., 2004, 26: 473-479 (doi: 10.1080/07060660409507167).

32. Ku rowski T.P., Wy s o cka U. Fungi colonizing grain of winter spelt grown under two production systems. Phytopathologia, 2009, 54: 45-52.

33. Ko n st a n t i n ov a P., Y 1 i - M a t t i l a T. IGS-RFLP analysis and development of molecular markers for identification of Fusarium poae, Fusarium langsethiae, Fusarium sporotrichioides and Fusarium kyushuense. Int. J. Food Microbiol., 2004, 95: 321-331 (doi: 10.1016/j.ijfoodmicro.2003.12.010).

34. S a ß V., M i 11 e s J., K rä m e r J., P r a ng e A. Competitive interactions of Fusarium graminearum and Alternaria alternata in vitro in relation to deoxynivalenol and zearalenone production. International Journal of Food, Agriculture and Environment, 2007, 5: 257-261.

35. M ü 11 e r M.E.H., U r b a n K., K öp p e n R., S i e g e 1 D., K o r n U., K o c h M. Mycotoxins as antagonistic or supporting agents in the interaction between phytopathogenic Fusarium and Alternaria fungi. World Mycotoxin J., 2015, 8(3): 311-321 (doi: 10.3920/WMJ2014.1747). 